\title{
Characterization of Acetyl-CoA: Lyso-PAF Acetyltransferase of Human Mesangial Cells
}

\author{
Elizabeth Fragopoulou, ${ }^{1}$ Christos Iatrou, ${ }^{2}$ and Constantinos Alexandros Demopoulos ${ }^{1}$ \\ ${ }^{1}$ Faculty of Chemistry, National and Kapodistrian University of Athens, Panepistimioupolis, 15771 Athens, Greece \\ ${ }^{2}$ Centre for Nephrology, G. Papadakis General Hospital of Nikea-Pireaus, 18454 Athens, Greece
}

Received 7 June 2005; accepted 30 June 2005

\begin{abstract}
Platelet activating factor (PAF) is a potent inflammatory mediator produced by various renal cells and it is implicated in renal pathology. The aim of this study is the characterization of remodeling lyso-PAF acetyltransferase, which is activated under inflammatory conditions, in human mesangial cell. Total membranes of mesangial cells were isolated and enzymatic activity and kinetic parameters were determined by trichloroacetic acid precipitation method. The effect of BSA, divalent cations, EDTA, and various chemicals on the activity of lyso-PAF acetyltransferase was also studied. Various detergents were also tested for the solubilization of the enzyme and only glycerol did not affect its activity. Partial purification of solubilized enzyme preparations of human kidney tissue and mesangial cells was performed on anion exchange column chromatography and native-PAGE electrophoresis and two active fractions were detected.
\end{abstract}

\section{INTRODUCTION}

Platelet activating factor (PAF, 1-O-alkyl-2-acetyl-snglycero-3-phosphocholine) [1] is a potent lipid mediator with a wide variety of biological activities related to physiological and pathological phenomena. Many different cells, including leukocytes, platelets, macrophages, neutrophils, lymphocytes, and endothelial cells can produce PAF under appropriate stimuli [2]. Two enzymatic pathways of PAF biosynthesis have been described [3]. The de novo pathway entails a specific stepwise sequence of reactions starting with the acetylation of 1-O-alkyl-snglycero-3-phosphate, which is an ether-linked metabolic intermediate formed soon after the ether bond is created. In contrast, the remodeling pathway involves a structural modification of preexisting ether-linked phospholipids that serve as structural components of membranes [3]. It is believed that the remodeling route plays a crucial role in inflammatory/hypersensitivity responses of cells whereas the de novo reaction sequence appears to be of physiological importance maintaining basal PAF levels in various tissues and blood. The main enzyme for PAF degradation is PAF-acetylhydrolase (PAF-AH) [4].

PAF in the kidney can be produced by both biosynthetic routes either by infiltrating inflammatory cells or

Correspondence and reprint requests to Constantinos Alexandros Demopoulos, Faculty of Chemistry, National and Kapodistrian University of Athens, Panepistimioupolis, 15771 Athens, Greece; demopoulos@chem.uoa.gr by intrinsic glomerular cells such as mesangial cells [5]. Mesangial cells account for $20 \%-25 \%$ of all glomerular cells. They are localized in the centre of the glomerular tuft and they have very important physiological functions including structural support of capillary net work, participation in filtration regulation, synthesis and secretion of matrix, eicosanoids, growth factors, and cytokines [6]. These cells are influenced by both autocrine and paracrine activities of the above factors. Apart from its physiological effects, the PAF produced in kidney is involved in the pathogenesis of renal damage $[7,8,9]$. PAF infusion into the renal artery of animals reduces the glomerular filtration rate and the renal blood flow, and increases proteinuria and glomerular permeability [9]. Moreover, increased levels of PAF and PAF-like lipids have been detected in experimental models of glomerulonephritis while parallel administration of PAF antagonists prevented or reduced renal damage [10]. In vitro experiments revealed that PAF has multiple actions in glomerular cells, especially in mesangial cells since it stimulates several signalling pathways [11], causes contraction [5] and matrix production [12]. These observations are supported by a limited number of clinical studies demonstrating increased PAF in patients with primary glomerulonephritis [13], IgA nephropathy [14], and membranous nephropathy [15].

The study of the enzymes of PAF metabolism is of great interest since they regulate PAF levels both intracellularly and extracellularly. Many of the features of progressive glomerular diseases share common biological mechanisms with those of atherosclerosis. Among 
them, inflammation is dominant. The last step in the remodeling pathway, which is activated under inflammatory conditions, is catalysed by the enzyme acetylCoA:1-O-alkyl-sn-glycero-3-phosphocholine acetyltransferase (lyso-PAF AT) (EC 2.3.1.67) which transfers an acetyl group in the sn-2 position of lyso-PAF. LysoPAF AT occurs in the microsomal fraction of a variety of tissues [16] and blood cells [17, 18]. The substrate specificity of the lyso-PAF AT is rather broad since 1-acyl-2-lysoglycerophosphocholine, 1-alky-1enyl2lysoglycerophosphoethanolamine, and other analogues serve as substrates. Similarly, short-chain acyl-CoAs (C2C6) can be used as substrates for the acetyltransferase [19]. Calcium has been reported to be necessary for the expression of lyso-PAF AT activity although contrasting evidence has been found [16, 20, 21]. Partial purification of the enzyme from rat spleen has been reported. Electrophoresis of the partially purified enzyme after the incorporation of labelled PAF revealed that the radioactivity was associated with a protein possessing a molecular mass of $29 \mathrm{kd}$ [22]. No subsequent experiments with purified preparations of the enzyme have been described, although solubilization of the enzyme with glycerol has been reported [23]. Lyso-PAF AT seems to be activated/inactivated by a phosphorylation/dephosphorylation mechanism $[24,25,26,27,28$, 29]. AMP-dependent protein kinase, calcium calmodulindependent protein kinase, protein kinase $\mathrm{C}$, and kinase p38 seem to be involved in the phosphorylation of the enzyme.

PAF-AH as well as remodeling and de novo acetyltransferases have been previously characterized in cortex and medulla from human kidney tissue by our laboratory $[20,30,31]$. Although PAF metabolism has been described in mesangial cells $[32,33]$, as far as we know there are no direct studies on PAF biosynthetic enzymes. In the present study, remodeling lyso-PAF AT was identified and characterized in human mesangial cell line while a partial purification on lyso-PAF AT from human kidney tissue and human mesangial cells is reported.

\section{MATERIAL AND METHODS}

\section{Materials and instrumentation}

All centrifugations were performed in a Sorvall RC5B refrigerated superspeed centrifuge (Sigma) apart from the centrifugation at $100000 \mathrm{xg}$, which was performed in a Heraeus-Christ, Omega 70000 ultracentrifuge (Hanau, Germany). For the precipitation of the bovine serum albumin (BSA) pellet, a Sigma $201 \mathrm{M}$ microcentrifuge was used (Sigma, Saint Louis, Mo, USA). The separation of protein was performed at $4^{\circ} \mathrm{C}$ on an HP HPLC Series 1100 liquid chromatography model (Hewlett Packard, Waldbronn, German) equipped with a $100 \mu \mathrm{L}$ Rheodyne (7725 i) loop valve injector, a degasser G1322A, a quat gradient pump G1311A, and an HP UV spectrophotometer G1314A as a detection system. The spectrophotometer was connected to a Hewlett- Packard (Hewlett Packard, Waldbronn, German) model HP-3395 integrator-plotter. An anion exchange column has been used for the separation of proteins (Resource Q, Amersham-Pharmacia Biotech AB).

Radioactivity was measured in a 1209 Rack Beta flexivial liquid scintillation counter (Pharmacia).

$\left[\mathrm{H}^{3}\right]$ acetyl-CoA (specific activity $200 \mathrm{mCi} / \mathrm{mmol}$ ) was obtained from ICN (Costa Mesa, Calif). Lyso-PAF (1-O-hexadecyl-2-lyso-sn-glycero-3-phosphocholine) and acetyl-CoA were purchased from Sigma Chemicals Co. 2, 5-diphenyloxazole (PPO) and 1, 4-Bis(5-phenyl-2oxazolyl) benzene (POPOP) were purchased from $\mathrm{BDH}$ Chemicals (Dorset, UK). Electrophoresis reagents were obtained from Bio-Rad (Hercules, Calif). RPMI 1640, foetal-calf serum (FCS), and trypsin-EDTA were from Gibco BRL (Paisley, UK) and all other reagents were from Sigma Chemicals Co (Saint Louis, Mo).

\section{Cell culture}

An established stable human mesangial cell line (HMC) was used in all the experiments (kindly donated by Dr Z. Varghese, Royal Free and University Collage Medical School, London, United Kingdom). HMCs were immortalized by transfection with T-SV40 and Hras oncogene, retaining many of the morphological and physiological features of normal human mesangial cells [34]. The cells were cultured in medium containing RPMI 1640, 5\% FCS, glutamine ( $2 \mathrm{mmol} / \mathrm{L})$, penicillin $\left(10^{5}\right.$ unit/L), streptomycin $(0.1 \mathrm{~g} / \mathrm{L})$, amphotericin $(2.5 \times$ $\left.10^{-3} \mathrm{~g} / \mathrm{L}\right)$, insulin-transferrin $\left(5 \times 10^{-3} \mathrm{~g} / \mathrm{L}\right)$, and sodium selenite $\left(5 \times 10^{-6} \mathrm{~g} / \mathrm{L}\right)$.

\section{Human kidney tissues}

Human kidney tissues were obtained from nephrectomized patients with adenocarcinoma. Immediately after the nephrectomy, the kidneys were perfused with normal saline and a speciment obtained of the apparently normal parenchyma and placed immediately in cold saline. Subsequently, all homogenization and subcellular fractionation procedures were completed in less than 3 hours.

\section{Homogenisation of kidney tissues and preparation of subcellular fractions}

Homogenisation of mesangial cells or kidney samples and preparation of subcellular fraction was carried out by a modification [20] of the method described by Lenihan and Lee [25]. Briefly, mesangial cells were cultured in $75 \mathrm{~cm}^{2}$ flasks, the pellet of the cells was resuspended in homogenisation buffer containing $0.25 \mathrm{M}$ sucrose, $10 \mathrm{mM}$ EDTA, $5 \mathrm{mM}$ mercaptoethanol (MeEtOH), $50 \mathrm{mM} \mathrm{NaF}$, $50 \mathrm{mM}$ Tris- $\mathrm{HCl}$ ( $\mathrm{pH} 7.4$ ), and were homogenized by sonication.

Kidney tissues were rinsed with ice-cold $0.25 \mathrm{M}$ sucrose, then minced and homogenized with six strokes of a motor-driven Potter-Elvehjem homogeniser in homogenisation buffer. The final concentration of the tissue 
in the homogenisation buffer was $10 \%$ w/v. Further homogenisation of the tissue by sonication was followed. In both cases, the homogenates were centrifuged at $500 \mathrm{xg}$ for 10 minutes. The pellets were discarded, a small portion of the supernatants was kept for protein and lyso-PAF AT determination and the rest of them were centrifuged at $100000 \mathrm{xg}$ for 1 hour. The resulting pellets, total membranes (TM), were suspended in suspension buffer containing $0.25 \mathrm{M}$ sucrose, $1 \mathrm{mM}$ DTT, $50 \mathrm{mM}$ Tris- $\mathrm{HCl}(\mathrm{pH}$ 7.4) (5-10 mg of protein/mL). All fractions were aliquoted and stored at $-20^{\circ} \mathrm{C}$. All homogenization and fractionation procedures were taken place at $4^{\circ} \mathrm{C}$.

\section{Lyso-PAF AT activity assay}

Lyso-PAF AT activity was measured by the method of trichloroacetic acid (TCA) previously described [20]. Unless stated otherwise, subcellular fractions of mesangial cells or kidney tissue, containing 10-50 $\mu \mathrm{g}$ of total protein, were incubated with $20 \mu \mathrm{M}$ of lyso-PAF and $200 \mu \mathrm{M}$ of $\left[\mathrm{H}^{3}\right]$-acetyl-CoA $(100 \mathrm{~Bq} / \mathrm{nmoL})$ for 30 minutes at $37^{\circ} \mathrm{C}$ in a final volume of $200 \mu \mathrm{L}$ of $50 \mathrm{mM}$ Tris- $\mathrm{HCl}$ buffer $(\mathrm{pH}$ 7.4) containing $0.25 \mathrm{mg} / \mathrm{mL}$ BSA. By the end of the incubation time $0.2 \mathrm{mg}$ of BSA were added and the reaction was stopped by the addition of cold TCA solution $9.6 \%$ final concentration. The reaction mixture was kept in ice for 30 minutes and centrifuged at $10000 \mathrm{xg}$ for 2 minutes. The supernatant was discarded and the pellet containing the $\left[\mathrm{H}^{3}\right]$ PAF bound to the denaturated BSA is dissolved in the scintillation cocktail (dioxane-base) and the radioactivity was determined by liquid scintillation counting. Matching controls were run in the absence of lyso-PAF in order to subtract the radioactivity of the endogenously produced $\left[\mathrm{H}^{3}\right] \mathrm{PAF}$.

\section{Solubilization of proteins}

For the solubilization of the proteins, total membranes fractions were suspended in Tris- $\mathrm{HCl}$ buffer $\mathrm{pH}$ 7.4 with different detergents in various concentrations (w.v.) and various ratios of detergent/protein (w.w.). The mixture was kept in ice for 40 minutes and it was centrifuged at $100000 \mathrm{xg}$ for 1 hour at $4^{\circ} \mathrm{C}$. The pellets were resuspended in suspension buffer. Both supernatants and resuspends pellets were tested for lyso-PAF AT activity and their protein concentration was determined.

\section{HPLC separation}

Supernatants were placed in two-compartment centrifuge tubes containing membranes with cutoff value of $10000 \mathrm{Da}$ and concentrated by centrifugation at $5000 \mathrm{xg}$ for 5 hours at $4^{\circ} \mathrm{C}$. The remaining concentrates were resuspended in Tris- $\mathrm{HCl} \mathrm{pH} 7.4$ and centrifuged at $5000 \mathrm{xg}$ for 2 hours at $4^{\circ} \mathrm{C}$ for the removal of the excess glycerol. The total volume of the sample after centrifugation was $50-200 \mu \mathrm{L}$. The separation was carried out on an anion exchange column. The elution system consisted of a linear gradient from, starting buffer containing $20 \mathrm{mM}$ Tris$\mathrm{HCl}$ pH 8.0 to elution buffer containing $20 \mathrm{mM}$ Tris- $\mathrm{HCl}$ and $0.5 \mathrm{M} \mathrm{KCl} \mathrm{pH} 8.0$ in 25 minutes. The flow rate was $0.8 \mathrm{~mL} / \mathrm{min}$ and UV detection was carried out at $280 \mathrm{~nm}$. One-minute fractions were collected for 30 minutes.

\section{ELECTROPHORESIS}

Nondenaturing electrophoresis was carried out by a method previously described by Laemmli [35], in which SDS was replaced by the nondenaturing 3-[(3-cholamidopropyl)-dimethylammonio]-1-propanesulfonate (CHAPS) (10 mM). Slab gels consisting of 12\% (w.v.) separating polyacrilamide gel in $1.5 \mathrm{M}$ Tris- $\mathrm{HCl}$, pH 8.8 were exposed to a constant $30 \mathrm{~mA}(250 \mathrm{~V})$ for 4.5 hours at $4^{\circ} \mathrm{C}$. The stacking gel was made up as a $4 \%$ (w.v.) gel in $0.5 \mathrm{M}$ Tris- $\mathrm{HCl} \mathrm{pH} \mathrm{6.5.} \mathrm{The} \mathrm{pH}$ of the electrophoresis buffer was 8.3. The samples were run in duplicate. Upon completion of electrophoresis, the gel was divided into two parts. The first part was sliced into $0.4 \mathrm{~cm}$ horizontal strips, which were individually extracted with $0.5 \mathrm{ml}$ Tris- $\mathrm{HCl} \mathrm{pH} \mathrm{7.4,} \mathrm{incubated,} \mathrm{overnight} \mathrm{at} 4^{\circ} \mathrm{C}$ and collected by centrifugation. The second part was stained by Coomassie Blue. Molecular markers (phosphatase- $\beta$ $97.4 \mathrm{kd}$, bovine serum albumin $66.2 \mathrm{kd}$, ovalbumin $45 \mathrm{kd}$, carbonic anhydrolase $31 \mathrm{kd}$, trypsin inhibitor $21.5 \mathrm{kd}$ ) were run in parallel with the samples.

\section{Analytical methods}

Protein was determined by the method of Bradford [36].

\section{Statistical analysis}

Unless otherwise stated, data are expressed as mean values \pm SD. The linear or nonlinear regressions of enzymes kinetics were made using GraphPad Prism. In order to compare the influence of several factors on enzyme activity, $t$ test for independent samples was performed on the specific activities values. All analyses were done with the Statistical Package for Social Sciences (SPSS, version 10.0, SPSS Inc, Chicago, Ill, USA). Differences were considered statistically significant at the 5\% level.

\section{RESULTS}

\section{Lyso-PAF AT activity of HMC and human kidney tissues}

The specific activity of lyso-PAF AT was measured in $500 \mathrm{xg}$ (homogenate fractions) and $100000 \mathrm{xg}$ (cytoplasmic fractions) supernatants as well as at $100000 \mathrm{xg}$ pellets (total membrane fractions) of mesangial cells or human kidney tissue preparations. The results are shown in Table 1. Lyso-PAF AT activity was detected in the $100000 \mathrm{xg}$ pellet. Heating of samples at $50^{\circ} \mathrm{C}$ and $60^{\circ} \mathrm{C}$ for $10 \mathrm{~min}$ utes resulted in $85 \%$ and $100 \%$ inactivation of the existing enzyme activity, respectively. Lyso-PAF AT specific activity was reduced $40 \%$ after a 20 -day storage at $-20^{\circ} \mathrm{C}$. All subsequent experiments were performed with total membrane (TM) preparations. 
TABLE 1. Subcellular specific activity of lyso-PAF AT from human kidney tissue and mesangial cell preparations.

\begin{tabular}{l|cc}
\hline & \multicolumn{2}{|c}{ Lyso-PAF AT specific activity $(\mathrm{nmol} / \mathrm{min} / \mathrm{mg})$} \\
Subcellular fraction & Human kidney tissue $(n=10)$ & Mesangial cells $(n=5)$ \\
\hline $500 \times$ x supernatant & $0.663 \pm 0.18$ & $1.43 \pm 0.030$ \\
100000 xg supernatant & $\mathrm{nd}^{\mathrm{a}}$ & $\mathrm{nd}$ \\
$100000 \mathrm{xg}$ pellet & $1.46 \pm 0.53$ & $2.52 \pm 0.20$ \\
\hline
\end{tabular}

and: not detected.

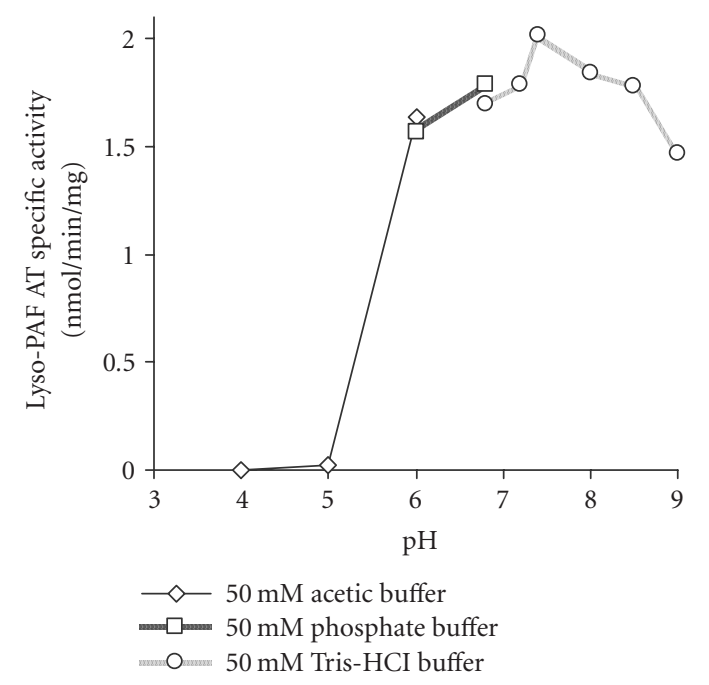

Figure 1. Effect of pH on lyso-PAF AT specific activity of mesangial cells: TM fractions of HMC $0.23 \mathrm{mg} / \mathrm{mL}$ were incubated in the presence of different buffer solutions. Results are the average of two independent determinations using different enzyme preparations performing duplicate samples.

\section{Effect of temperature and $\mathrm{pH}$ on lyso-PAF AT activity of HMC}

Experiments were carried out in order to found the optimum conditions for the action of the enzyme. The temperature-activity profile was bell-shaped showing an optimum at $37^{\circ} \mathrm{C}$. Three different buffer solutions of various $\mathrm{pH}$ values, namely, $50 \mathrm{mM}$ acetic buffer $\mathrm{pH} 4-6$, $50 \mathrm{mM}$ phosphate buffer $\mathrm{pH} 6-7$, and Tris- $\mathrm{HCl}$ buffer $\mathrm{pH}$ $7-9$, were utilized in order to investigate the dependence of lyso-PAF AT activity on $\mathrm{pH}$. The results are shown in Figure 1. Lyso-PAF AT showed maximum activity at a $\mathrm{pH}$ range between 7.2 and 7.4 .

\section{Effect of BSA on lyso-PAF AT activity of HMC}

The effect of BSA concentration on the activity of total membrane fractions of lyso-PAF AT was studied. As shown in Figure 2, the maximum enzyme activity occurred at $0.25 \mathrm{mg} / \mathrm{mL}$ BSA final concentration in reaction mixture while $2.0 \mathrm{mg} / \mathrm{mL}$ BSA reduced the activity by $15 \%$ compared to the non-added control. The $t$ test for independent samples revealed that only $0.25 \mathrm{mg} / \mathrm{ml}$ concentration of BSA gave statistical significance difference

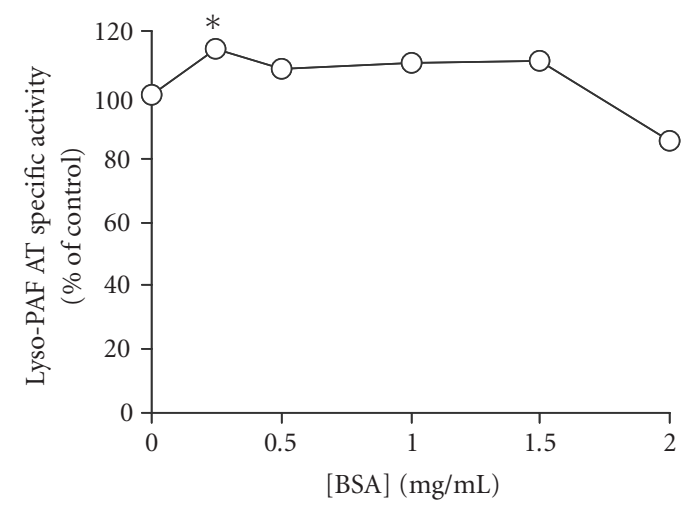

Figure 2. Effect of BSA concentration on lyso-PAF AT specific activity of mesangial cells: TM fractions of HMC $0.23 \mathrm{mg} / \mathrm{mL}$ were incubated in the presence of different concentrations of BSA. Results are expressed as percent related to non-added control $(100 \%)$. Results are the average of two independent determinations using different enzyme preparations performing duplicate samples. ${ }^{*} P<.05$ versus control.

from the non-added control value $(P=.049)$. Therefore, $0.25 \mathrm{mg} / \mathrm{mL}$ final concentration BSA was routinely used.

\section{Dependence of PAF formation by protein concentration and incubation time}

The kinetics of PAF formation in relation to time and the dependence of TM lyso-PAF AT activity on protein concentration are shown in Figure 3. The total amount of PAF formed at the end of each incubation time decreased as protein concentration decreased (Figure 3a). A linear relationship between the initial velocity and total protein up to $0.05 \mathrm{mg}(0.25 \mathrm{mg} / \mathrm{mL})$ was found for 30 -minute incubation time (Figure $3 \mathrm{~b}$ ). In order to achieve the maximum yield of reaction $0.02-0.05 \mathrm{mg}(0.1-0.25 \mathrm{mg} / \mathrm{mL})$ protein and 30-minute incubation time were routinely used.

\section{Effect of substrates concentration on lyso-PAF AT activity and kinetic parameters}

The activity of lyso-PAF AT was determined at different acetyl-CoA concentrations ranging from 25 to $800 \mu \mathrm{M}$ at a fixed concentration of lyso-PAF $20 \mu \mathrm{M}$. The results revealed that enzyme exhibited classical Michaelis-Menten kinetics with respect to acetyl-CoA. When the concentration of lyso-PAF was varied between 2.5 and $100 \mu \mathrm{M}$ at a fixed concentration of acetyl-CoA $(200 \mu \mathrm{M})$, the enzyme followed simple saturation kinetics only up to $40 \mu \mathrm{M}$. 


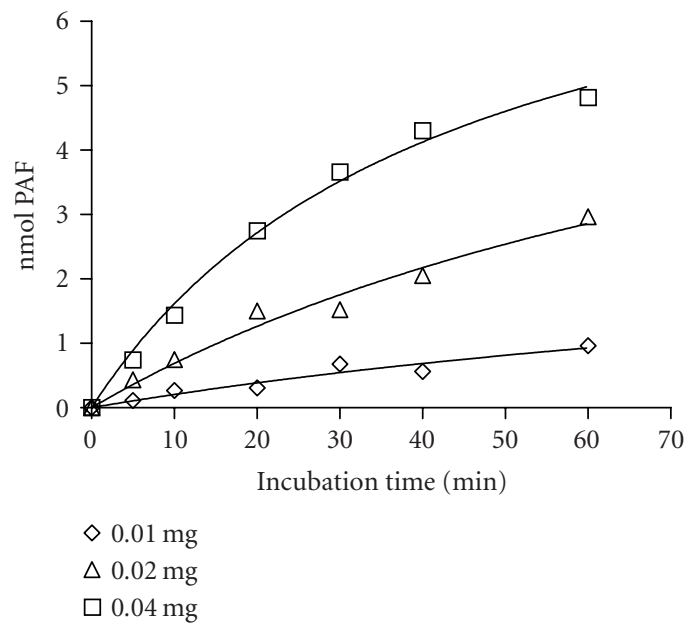

(a)

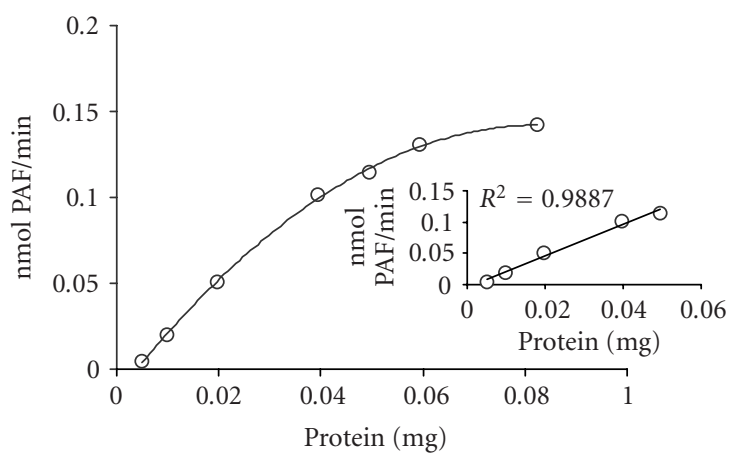

(b)

FIgURE 3. Dependence of PAF formation by incubation time and protein concentration: (a) time course of PAF production using $0.01,0.02,0.04 \mathrm{mg}$ total protein; (b) lyso-PAF AT activity as a function of protein concentration at a fixed incubation time 30 minutes. Experiments were performed with total membrane fractions of HMC in the present of $20 \mu \mathrm{M}$ lyso-PAF and $200 \mu \mathrm{M}$ acetyl-CoA. Results are the average of two independent determinations using different enzyme preparations performing duplicate samples.

Higher concentrations of lyso-PAF resulted in a drop of enzyme activity that was consistent with previously published data [20, 27].

The kinetic parameters of the enzyme revealed from these experiments are summarized in Table 2. The calculations for acetyl-CoA were made using nonlinear regression while the calculations for lyso-PAF were made using linear regression (Lineweaver-Burk plot) since there was no classical saturation curve.

\section{Effect of divalent cations on lyso-PAF AT activity of HMC}

In order to study the effect of divalent cations $\left(\mathrm{Ca}^{2+}\right.$ and $\mathrm{Mg}^{2+}$ ) on the activity of lyso-PAF AT, $0.15 \mathrm{mg} / \mathrm{mL}$ of TM were incubated in the presence of various concentrations of $\mathrm{CaCl}_{2}$ and $\mathrm{MgCl}_{2}$. Low concentrations
TABLE 2. Kinetics parameters of lyso-PAF AT of total membrane fractions of mesangial cells $(n=5)$.

\begin{tabular}{l|cc}
\hline & $\begin{array}{c}\mathrm{K}_{\mathrm{M}} \text {, app } \\
(\mu M)\end{array}$ & $\begin{array}{c}\text { Vmax, app } \\
(\mathrm{nmol} / \mathrm{min} / \mathrm{mg})\end{array}$ \\
\hline Lyso-PAF $^{\mathrm{a}}$ & $9.21 \pm 2.37$ & $2.69 \pm 0.311$ \\
Acetyl-CoA $^{\mathrm{b}}$ & $71.2 \pm 15.1$ & $2.83 \pm 0.252$ \\
\hline
\end{tabular}

${ }^{a}$ Kinetic data were obtained from experiments shown in Figure 4. Initial velocity data were analyzed by weighted fits to the Michaelis-Menten equation using linear regression for up to $40 \mu \mathrm{M}$ lyso-PAF from GraphPad Prism.

${ }^{b}$ Kinetic data were obtained from experiments shown in Figure 4. Initial velocity data were analyzed by weighted fits to the Mechaelis-Menten equation using nonlinear regression programme adapted from GraphPad Prism.

TABle 3. Effect of divalent cations and chemicals on TM lysoPAF AT activity. Results are the average of two independent determinations using different enzyme preparations performing duplicate samples.

\begin{tabular}{c|cc}
\hline & $\begin{array}{c}\text { Concentration } \\
(\mathrm{M})\end{array}$ & $\begin{array}{c}\text { Lyso-PAF AT specific } \\
\text { activity (\% of control) }\end{array}$ \\
\hline $\mathrm{MgCl}_{2}$ & $10^{-4}$ & 101 \\
$\mathrm{MgCl}_{2}$ & $10^{-3}$ & 94 \\
$\mathrm{MgCl}_{2}$ & $10^{-2}$ & 81 \\
$\mathrm{CaCl}_{2}$ & $10^{-5}$ & 94 \\
$\mathrm{CaCl}_{2}$ & $10^{-4}$ & 104 \\
$\mathrm{CaCl}_{2}$ & $10^{-3}$ & 108 \\
$\mathrm{CaCl}_{2}$ & $10^{-2}$ & $54^{*}$ \\
$\mathrm{EDTA}$ & $10^{-3}$ & $53^{*}$ \\
$\mathrm{EDTA}+\mathrm{CaCl}_{2}$ & $10^{-3}+10^{-2}$ & 70 \\
\hline
\end{tabular}

${ }^{*} P<.05$ versus control.

$10^{-5}-10^{-3} \mathrm{M}$ of $\mathrm{Ca}^{2+}$ and $\mathrm{Mg}^{2+}$ did not influence the activity of lyso- PAF AT while at higher concentration $\mathrm{Ca}^{2+}$ and $\mathrm{Mg}^{2+}\left(10^{-2} \mathrm{M}\right)$ significantly $(P<.05)$ reduced lysoPAF AT activity by 46 and $19 \%$, respectively. When TM were incubated in the presence of ethylene-diamino-tetraacetic acid (EDTA) $10^{-3} \mathrm{M}$ the enzyme activity was significantly $(P<.05)$ reduced by $47 \%$ while the addition of $\mathrm{Ca}^{2+} 10^{-2} \mathrm{M}$ partially overrode this reduction $(P=.097)$ (Table 3).

\section{EFFECT OF CHEMICALS ON LYSO-PAF AT ACTIVITY OF HMC}

The effect of various chemicals on lyso-PAF AT activity was also studied. The results are summarized in Figure 5. Sulfonyl-type serine protease inhibitors like Pefabloc did not influence the activity of lyso-PAF AT. The protease inhibitor $\mathrm{NaF}$ (sodium fluoride) slightly increases 


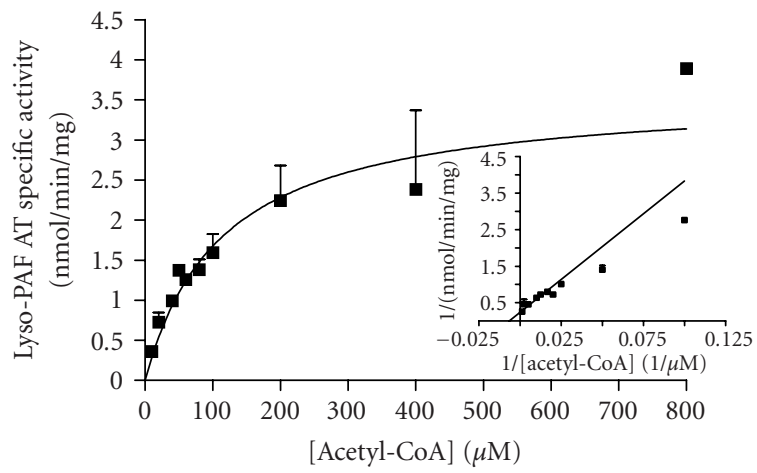

(a)

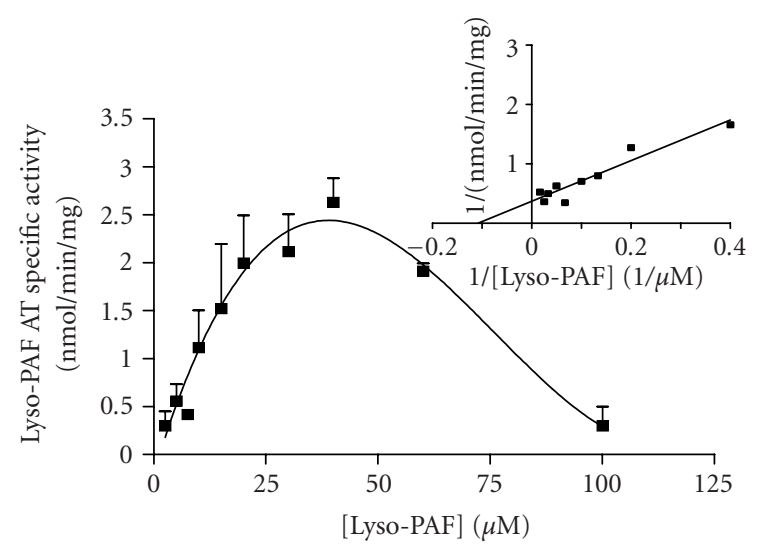

(b)

FIGURE 4. Effect of substrate concentration on lyso-PAF AT activity: (a) activity of lyso-PAF AT as a function of acetyl-CoA at fixed concentration of lyso-PAF $(20 \mu \mathrm{M})$; (b) activity of lyso-PAF AT as a function of lyso-PAF at fixed concentration of acetylCoA $(200 \mu \mathrm{M})$. Experiments were performed at total membrane fractions using $0.23 \mathrm{mg} / \mathrm{mL}$ protein in optimum conditions. Results represent the average \pm SD from four independent determinations using different enzyme preparations performing duplicate samples.

the activity of the enzyme. Dithiothreitol (DTT) inhibited enzyme activity with a dose-dependent manner. Since DTT reduces disulfide bridges present in polypeptides and proteins, this result indicates the presence of disulfide bridges in the enzyme. Moreover, mercaptoethanol had the same action with DTT supporting the existence of disulfide groups (Figure 5). The $t$ test for independent samples revealed that only DTT at $5 \mathrm{mM}$ and mercaptoethanol reduced significant the activity of the enzyme with $P$ values .000 and .035 , respectively.

\section{PARTIAL PURIFICATION PROCEDURE}

\section{Solubilization of total membranes}

An essential step in purifying the membrane enzyme is to solubilize the enzyme from the membranes. For this purpose, total membrane fractions from human kidney

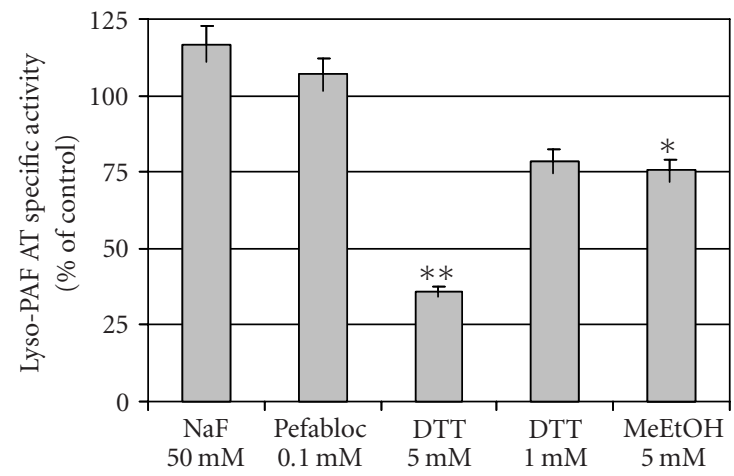

FIgURE 5. Effect of chemicals on lyso-PAF AT activity: Total membrane fractions of HMC $0.23 \mathrm{mg} / \mathrm{mL}$ were incubated in the presence of various chemicals. Results represent the average two independent determinations using different enzyme preparations performing duplicate samples and are expressed as percent related to non-added control (100\%). (DTT; Dithiothreitol, $\mathrm{MeETOH}$; mercaptoethanol, NaF; sodium fluoride) ${ }^{*} P<.05$, ${ }^{* *} P<.005$ versus control.

tissue were used. All attempts to solubilize total membrane fractions by sonication, in the absence of detergents, were unsuccessful, therefore total membranes were incubated with various solubilizing agents. Lyso-PAF AT activity and the protein concentration were measured in the supernatants and the pellets. A control in absence of detergent was run concomitantly and the values were expressed as the \% specific activity of lyso-PAF AT in the supernatants of the solubilization procedure compared to the non-added control (\% non-added control). We tried the ionic detergent sodium deoxycholate (0.2-0.40.6-0.8-1.0\% w.v), the nonionic detergents Triton X-100 (0.24-0.84-1.5\% w.v), Tween 80 (0.2-0.4-0.8\% w.v), the steroid-based detergents CHAPS (0.2-0.4-0.8\% w.v), digitonin (0.2-0.67-1.25 \% w.v), and glycerol (3.2-6.4-16-32$64 \%$ w.v). Although all detergents were successfully solubilized protein, glycerol was the only detergent able to solubilize the enzyme without inactivating it. As shown in Table 4, the higher the glycerol concentration, the more effective the enzyme solubilization. Therefore, routine solubilization of TM fractions from human kidney tissue and HMC was carried out with 30\% w.w. glycerol (glycerol/protein 167 w.w.) for routine process. Higher glycerol concentration made the removal of it difficult in the next steps of purification. The kinetics parameters of the solubilized fractions from HMC were also studied. These experiments revealed $K_{M}$, app and Vmax,app values of TM and solubilized fractions $51.2 \mu \mathrm{M}, 2.96 \mathrm{nmol} / \mathrm{min} / \mathrm{mg}$ and $42.0 \mu \mathrm{M}, 2.05 \mathrm{nmol} / \mathrm{min} / \mathrm{mg}$, respectively, with respect to acetyl-CoA and $11.3 \mu \mathrm{M}, 3.17 \mathrm{nmol} / \mathrm{min} / \mathrm{mg}$ and $12.4 \mu \mathrm{M}$, $2.86 \mathrm{nmol} / \mathrm{min} / \mathrm{mg}$, respectively, with respect to lyso-PAF.

\section{lon exchange chromatography - HPLC}

In order to perform chromatographic separation, the solubilized enzyme fractions had to be concentrated. All attempts made to lyophilize the solubilized fractions 
TABLE 4. Effects of glycerol concentrations on the solubilization of lyso-PAF AT from membrane fraction of human kidney tissue. Data represent the average of two experiments with duplicate determinations.

\begin{tabular}{cccccc}
\hline $\begin{array}{c}\text { Glycerol } \\
(\% \text { w.v. })\end{array}$ & $\begin{array}{c}\text { Glycerol/Protein } \\
\text { (w.w.) }\end{array}$ & $\begin{array}{c}\text { Protein in supernatant } \\
\text { (\% of total protein) }\end{array}$ & $\begin{array}{c}\text { Specific activity } \\
\text { (\% of control) }\end{array}$ & Yield (\%) & Purification \\
\hline 3.2 & 20 & 15.9 & 56 & 6.82 & 0.45 \\
6.4 & 40 & 18.7 & 71 & 8.77 & 0.49 \\
16 & 100 & 16.78 & 290 & 18.0 & 1.12 \\
32 & 200 & 17.7 & 396 & 24.1 & 1.43 \\
64 & 400 & 26.5 & 740 & 61.1 & 2.42 \\
\hline
\end{tabular}

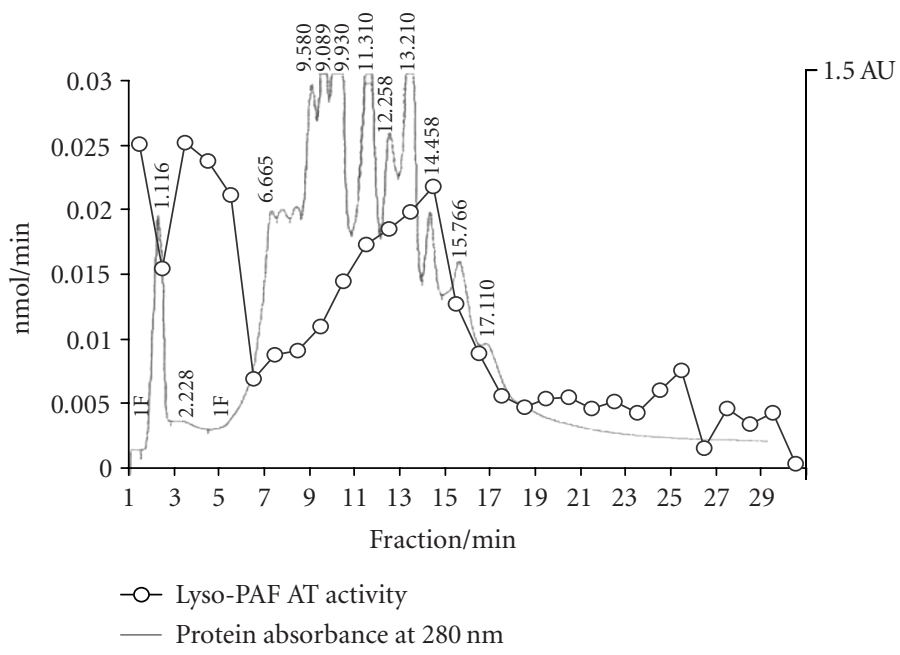

(a)

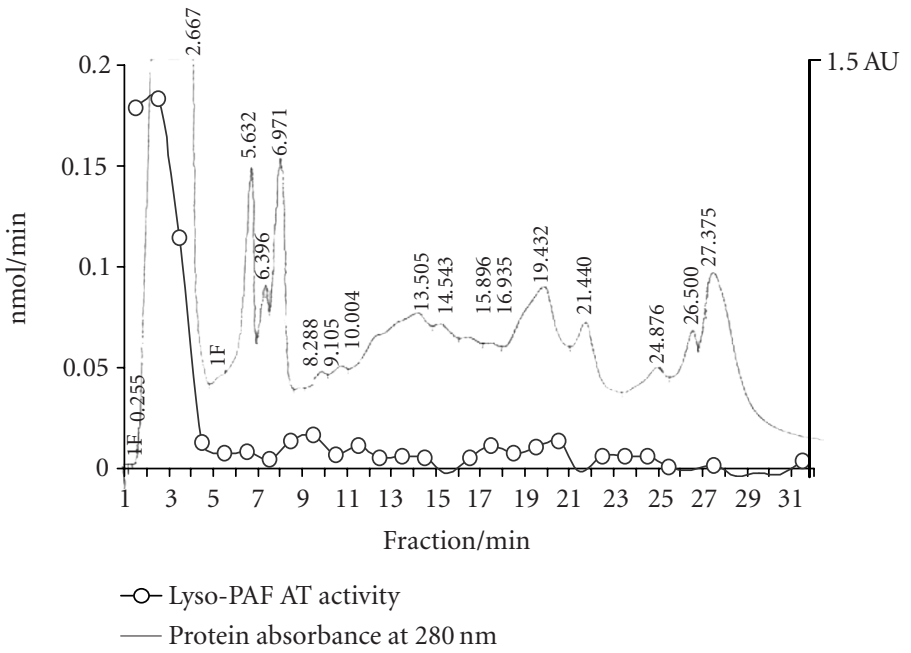

(b)

FIGURE 6. Ion exchange chromatography of solubilized fractions. Typical chromatographic purification and activities of lyso-PAF AT on fractions of (a) solubilized fractions of human kidney tissue and (b) solubilized fractions of HMC.

resulted in enzyme inactivation, for this reason, ultrafiltration using two compartment centrifuge tubes was carried out as described in methods. The solubilized concentrated fractions of human kidney tissue and HMC were subjected to HPLC separation under the conditions described in methods. Lyso-PAF AT activity of human kidney tissue was recovered in fractions $1,2-4$, and 1015 while the respective activity of the HMC in fractions 1-3 (Figure 6). The apparent $K_{M}$,app and Vmax,app values with respect to lyso-PAF AT of HPLC active fractions 
from HMC were $19.2 \mu \mathrm{M}, 2.52 \mathrm{nmol} / \mathrm{min} / \mathrm{mg}$. The yield of this step was 10.2 and purification 1.6.

\section{Nondenaturing electrophoresis}

The solubilized fraction from human kidney tissue, since there was not enough amount after the HPLC separation, and the active HPLC fractions 1-2 from mesangial cells were subjected to gel-electrophoresis according to methods. The activity of the lyso-PAF AT was present in two gel fragments corresponding to apparent molecular weight values of 25-30 kd of human kidney tissue, 75$85 \mathrm{kd}$ of human kidney tissue, and 25-30 kd and 65-80 kd of HMC (Figure 7). The calculation of apparent molecular weight was made based on the $\log M W=f\left(R_{f}\right)$ function, which under the electrophoresis conditions was linear $\left(y=-1.045 x+4.97, R^{2}=0.9875\right)$. The enzyme specific activity of the active fragment $(25-30 \mathrm{kd})$ of HMC after nondenature PAGE was $2.78 \mathrm{nmol} / \mathrm{min} / \mathrm{mg}$. The yield of this step was 0.01 and purification 1.9.

\section{DISCUSSION}

Platelet activating factor is a potent phospholipid mediator that is produced by a variety of tissues and cells $[1,2]$. The balance between PAF biosynthesis and degradation determines its levels. De novo biosynthesis pathway is thought to be responsible for the resting state levels of PAF while the remodeling pathway is thought to play a crucial role in inflammatory responses. Degradation of PAF occurs mainly with PAF-AH, which converts it to inactive lyso-PAF. Although many studies exist for PAF-AH, which has been cloned, there are not many studies about biosynthetic enzymes of PAF metabolism. Lyso-PAF AT is the main enzyme in remodeling pathway and converts lyso-PAF to PAF using acetyl-CoA as acetyl donor.

We have previously detected and characterized lysoPAF AT activity in cortex and medulla of human kidney tissue [20]. In this study, we detected and characterized lyso-PAF AT in human mesangial cells. Mesangial cells are the main source of PAF in kidney and as far as we know there is no any study on lyso-PAF AT in mesangial cells.

As previously described from others and us, the activity of lyso-PAF AT has been detected on mitochondria and microsomal fractions $[20,21,27]$. In order to have the maximum enzyme amount, total membranes fractions were used for the process. Total membranes lyso-PAF activity was abolished when samples were pre-incubated at $60^{\circ} \mathrm{C}$ for 10 minutes. Maximum lyso-PAF AT activity was obtained at $\mathrm{pH} 7.4$ and at incubation temperature $37^{\circ} \mathrm{C}$ while dependence of enzyme activity on total protein showed linearity up to $50 \mu \mathrm{g}(250 \mu \mathrm{g} / \mathrm{mL})$. Assays of acetyltransferase with lyso-PAF as a substrate are routinely performed in the presence of BSA, which binds $\mathrm{PAF}$ as it is formed [34]. It has been reported that 0.75$2.5 \mathrm{mg} / \mathrm{mL}$ BSA in the presence of low protein concentration $(10-60 \mu \mathrm{g} / \mathrm{mL})$ activates lyso-PAF AT while higher

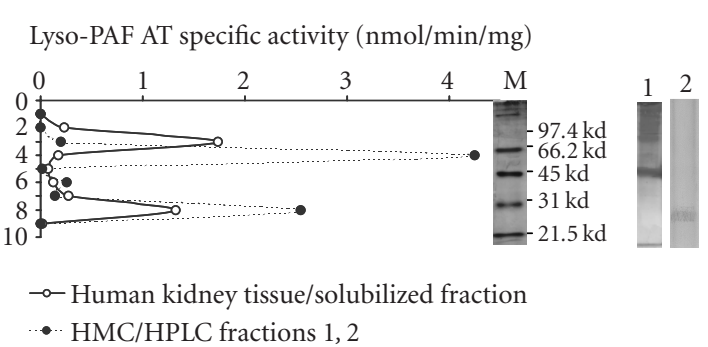

Figure 7. Native-PAGE electrophoresis: Lyso-PAF AT specific activities on native PAGE electrophoresis of solubilized fractions of human kidney tissue (-o-) and active HPLC fractions 1, 2 of mesangial cells (-•-). The Log MW of standard proteins versus mobility was linear. Lines $M, 1$, and 2 represent the part of the gel stained by Coomassie Blue from molecular markers, human kidney tissue, and $\mathrm{HMC}$, respectively.

protein concentration $(200 \mu \mathrm{g} / \mathrm{mL})$ showed no significant effect. In the present study $230 \mu \mathrm{g} / \mathrm{mL}$ of protein was used and BSA significantly increased $(P<.05)$ the activity of lyso-PAF AT at $0.25 \mathrm{mg} / \mathrm{mL}$ while at higher concentration caused a slightly not significant reduction of lyso-PAF AT activity. This result is with agreement with previous report that demonstrating that the membranes could be also effective in binding PAF [32].

Regarding the effect of substrates on lyso-PAF AT activity the experiments revealed that lyso-PAF AT followed typical Michaelis-Menten kinetic profile with respect to acetyl-CoA while followed simple saturation kinetics with respect to lyso-PAF only up to $50 \mu \mathrm{M}$. Higher concentrations of lyso-PAF resulted in a drop of enzyme activity. This is consistent with previous data from our laboratory and others and probably due to detergent effect of lysophospholipids [20,37].

Exogenous addition of the divalent cations $\mathrm{Ca}^{2+}$ and $\mathrm{Mg}^{2+}\left(10^{-2} \mathrm{M}\right)$ at high concentrations reduced the enzyme activity. EDTA inhibited the lyso-PAF AT activity and this inhibition is partially reversed by the addition of $\mathrm{Ca}^{2+}$. It seems that lyso-PAF AT required a specific concentration of $\mathrm{Ca}^{+2}$ for its activation and that higher or lower concentration resulting in inactivation. It has been reported that $\mathrm{Ca}^{2+}$ is required for the lyso-PAF activity $[20,38]$ but others have been indicated otherwise [16].

DTT and mercaptoethanol significantly $(P<.000$ and $P<.05$, respectively) inhibited lyso-PAF acetyltranserase indicating that there are disulfide bridges present in the enzyme. Pefabloc had no significant effect on the enzyme action supporting the absence of serine(s) in the active site of the enzyme. In addition, pefabloc is a PAF AH inhibitor and it seems that the possible presence of PAF $\mathrm{AH}$ in the assay did not influence PAF formation, which is in agreement with our previous results [20].

Lyso-PAF AT is a very labile enzyme that is very sensitive to detergents. Solubilization of the enzyme from other tissues with sodium deoxycholate and glycerol has already been reported $[22,23,24]$. In the present study, most of the common detergents used resulted in total inactivation 
of the enzyme and only glycerol managed to solubilize the enzyme without inactivation. Concentration of $32 \% \mathrm{w} . \mathrm{w}$ glycerol had a $24 \%$ yield in the solubilization of human kidney tissue and human mesangial cells lyso-PAF AT. Furthermore, an attempt was made to purify lysoPAF AT from human kidney tissue and human mesangial cells. The partial purification procedure consisted of only two steps, namely, anion exchange chromatography and native-PAGE electophoresis, since the limited amount of enzyme preparation along with the low recovery rate, especially in human kidney tissues, prevented us from utilizing a more extensive purification process. Native-PAGE electrophoresis of the partially purified enzyme from human kidney tissue and HMC resulted in two active fractions in both cases of approximately 25-30 kd and 75$85 \mathrm{kd}$ molecular weight. A $30 \mathrm{kd}$ band of lyso-PAF AT activity from rat spleens after nondenaturing conditions electrophoresis has been reported [24]. More investigation is required in order to explain if the one band is due to an enzyme dimmer formation or to another isoenzyme or more possible to an enzyme comlex with membrane fractions.

These data demonstrate that lyso-PAF acetyltranferase activity is present in human mesangial cells and established the biochemical properties of this enzyme for the first time in human mesangial cells. Concerning our previous data, lyso-PAF AT of mesangial cells seems to have similar properties with lyso-PAF AT characterized in human kidney tissue (medulla and cortex), supporting that mesangial cells are the primary source of PAF in the kidney. Moreover, solubilization and partial purification of human kidney tissue and mesangial cells lyso-PAF AT were achieved.

PAF production in kidney, mainly by mesangial cells, is involved in the pathogenesis of renal damage. The characterization of lyso-PAF AT activity in human mesangial cells enables the further investigation of lyso-PAF AT regulatory mechanisms and therefore PAF production under inflammatory conditions.

\section{REFERENCES}

[1] Demopoulos CA, Pinckard RN, Hanahan DJ. Platelet-activating factor. Evidence for 1-O-alkyl -2acetyl-sn-glyceryl-3-phosphorylcholine as the active component (a new class of lipid chemical mediators). J Biol Chem. 1979;254(19):9355-9358.

[2] Prescott SM, Zimmerman GA, Stafforini DM, McIntyre TM. Platelet-activating factor and related lipid mediators. Annu Rev Biochem. 2000;69:419-445.

[3] Snyder F, Fitzgerald V, Blank ML. Biosynthesis of platelet-activating factor and enzyme inhibitors. $A d v$ Exp Med Biol. 1996;416:5-10.

[4] Stafforini DM, McIntyre TM, Carter ME, Prescott SM. Human plasma platelet-activating factor acetylhydrolase. Association with lipoprotein particles and role in the degradation of platelet-activating factor. $J$ Biol Chem. 1987;262(9):4215-4222.
[5] Schlondorff D, Neuwirth R. Platelet-activating factor and the kidney. Am J Physiol. 1986;251(1 pt 2):F111.

[6] Schlondorff D. Roles of the mesangium in glomerular function. Kidney Int. 1996;49(6):1583-1585.

[7] Ortiz A, Gomez-Chiarri M, Lerma JL, Gonzalez E, Egido J. The role of platelet-activating factor (PAF) in experimental glomerular injury. Lipids. 1991;26(12):1310-1315.

[8] Camussi G. Potential role of platelet-activating factor in renal pathophysiology. Kidney Int. 1986; 29(2):469-477.

[9] Camussi G, Tetta C, Coda R, Segoloni GP, Vercellone A. Platelet-activating factor-induced loss of glomerular anionic charges. Kidney Int. 1984; 25(1):73-81.

[10] Lopez-Novoa JM. Potential role of platelet activating factor in acute renal failure. Kidney Int. 1999;55(5):1672-1682.

[11] Kester M, Thomas CP, Wang J, Dunn MJ. Plateletactivating factor stimulates multiple signaling pathways in cultured rat mesangial cells. J Cell Physiol. 1992;153(2):244-255.

[12] Ruiz-Ortega M, Bustos C, Plaza JJ, Egido J. Overexpression of extracellular matrix proteins in renal tubulointerstitial cells by platelet-activatingfactor stimulation. Nephrol Dial Transplant. 1998; 13(4):886-892.

[13] Iatrou C, Moustakas G, Antonopoulou S, Demopoulos CA, Ziroyiannis P. Platelet-activating factor levels and Paf acetylhydrolase activities in patients with primary glomerulonephritis. Nephron. 1996;72(4):611-616.

[14] Denizot Y, Aupetit C, Bridoux F, Alphonse JC, Cogne M, Aldigier JC. Deregulated platelet-activating factor levels and acetylhydrolase activity in patients with idiopathic IgA nephropathy. Nephrol Dial Transplant. 2000;15(9):1344-1347.

[15] Noris M, Benigni A, Boccardo P, et al. Urinary excretion of platelet activating factor in patients with immune-mediated glomerulonephritis. Kidney Int. 1993;43(2):426-429.

[16] Wykle RL, Malone B, Snyder F. Enzymatic synthesis of 1-alkyl-2-acetyl-sn-glycero-3-phosphocholine, a hypotensive and platelet-aggregating lipid. J Biol Chem. 1980;255(21):10256-10260.

[17] Lee TC, Malone B, Wasserman SI, Fitzgerald $\mathrm{V}$, Snyder F. Activities of enzymes that metabolize platelet-activating factor (1-Alkyl-2-acetylsn-glycero-3-phosphocholine) in neutrophils and eosinophils from humans and the effect of a calcium ionophore. Biochem Biophys Res Commun. 1982;105(4):1303-1308.

[18] Ribbes G, Ninio E, Fontan P, et al. Evidence that biosynthesis of platelet-activating factor (pafacether) by human neutrophils occurs in an intracellular membrane. FEBS Lett. 1985;191(2):195199. 
[19] Snyder F, Lee TC, Blank ML. Platelet-activating factor and related ether lipid mediators. Biological activities, metabolism, and regulation. Ann N Y Acad Sci. 1989;568:35-43.

[20] Nomikos TN, Iatrou C, Demopoulos CA. AcetylCoA:1-O-alkyl-sn-glycero-3-phosphocholine acetyltransferase (lyso-PAF AT) activity in cortical and medullary human renal tissue. Eur J Biochem. 2003;270(14):2992-3000.

[21] Gomez-Cambronero J, Nieto ML, Mato JM, Sanchez-Crespo M. Modulation of lyso-plateletactivating factor: acetyl-CoA acetyltransferase from rat splenic microsomes. The role of calcium ions. Biochim Biophys Acta. 1985;845(3):511-515.

[22] Gomez-Cambronero J, Velasco S, Sanchez-Crespo M, Vivanco F, Mato JM. Partial purification and characterization of 1-O-alkyl-2-lyso-sn-glycero-3phosphocholine:acetyl-CoA acetyltransferase from rat spleen Biochem J. 1986;237(2):439-445.

[23] Seyama K. Studies on acetyl-CoA:lyso platelet activating factor acetyltransferase of rat spleen microsomes-solubilization and substrate specificity. Hokkaido Igaku Zasshi. 1986;61(5):766-775.

[24] Gomez-Cambronero J, Mato JM, Vivanco F, Sanchez-Crespo M. Phosphorylation of partially purified 1-O-alkyl-2-lyso-sn-glycero-3phosphocholine:acetyl-CoA acetyltransferase from rat spleen. Biochem J. 1987;245(3):893-897.

[25] Lenihan DJ, Lee TC. Regulation of platelet activating factor synthesis: modulation of 1-alkyl-2-lyso-snglycero-3-phosphocholine:acetyl-CoA acetyltransferase by phosphorylation and dephosphorylation in rat spleen microsomes. Biochem Biophys Res Commun. 1984;120(3):834-839.

[26] Nieto ML, Velasco S, Sanchez Crespo M. Modulation of acetyl-CoA:1-alkyl-2-lyso-sn-glycero3-phosphocholine (lyso-PAF) acetyltransferase in human polymorphonuclears. The role of cyclic amp-dependent and phospholipid sensitive, calcium-dependent protein kinases. J Biol Chem. 1988;263(10):4607-4611.

[27] Ninio E, Joly F, Hieblot C, Bessou G, Mencia-Huerta JM, Benveniste J. Biosynthesis of paf-acether. IX. Role for a phosphorylation-dependent activation of acetyltransferase in antigen-stimulated mouse mast cells. J Immunol. 1987;139(1):154-160.

[28] Baker PR, Owen JS, Nixon AB, et al. Regulation of platelet-activating factor synthesis in human neutrophils by map kinases. Biochim Biophys Acta. 2002;1592(2):175-184.

[29] Bernatchez PN, Allen BG, Gelinas DS, Guillemette G, Sirois MG. Regulation of VEGF-induced endothelial cell PAF synthesis: role of p42/44 MAPK, p38 MAPK and PI3k pathways. Br. J. Pharmacol. 2001;134(6):1253-1262.

[30] Antonopoulou S, Demopoulos CA, Iatrou C, Moustakas G, Zirogiannis P. Platelet-activating factor acetylhydrolase (PAF-AH) in human kidney. Int $J$ Biochem. 1994;26(9):1157-1162.

[31] Nomikos TN, Iatrou C, Demopoulos CA. Application of a TCA-precipitation method for the determination of 1-alkyl-sn-glycero-3-phosphate: Acetyl-CoA acetyltransferase in human renal tissue. Prostaglandins Other Lipid Mediat. 2004;73(12):123-140.

[32] Neuwirth R, Ardaillou N, Schlondorff D. Extra- and intracellular metabolism of platelet-activating factor by cultured mesangial cells. Am J Physiol. 1989;256(4 pt 2):F735-F741.

[33] Lianos EA, Zanglis A. Biosynthesis and metabolism of 1-O-alkyl-2-acetyl-sn-glycero-3-phosphocholine in rat glomerular mesangial cells. J Biol Chem. 1987;262(19):8990-8993.

[34] Sraer JD, Delarue F, Hagege J, et al. Stable cell lines of T-SV40 immortalized human glomerular mesangial cells. Kidney Int. 1996;49(1):267-270.

[35] Laemmli UK. Cleavage of structural proteins during the assembly of the head of bacteriophage T4. Nature. 1970;227(5259):680-685.

[36] Bradford MM, Williams WL. New, rapid, sensitive method for protein determination. Federation Proceedings. 1976;35:274.

[37] Ninio E, Joly F, Bessou G. Biosynthesis of pafacether. XI. Regulation of acetyltransferase by enzyme-substrate imbalance. Biochim Biophys Acta. 1988;963(2):288-294.

[38] Gomez-Cambronero J, Inarrea P, Alonso F, Sanchez Crespo M. The role of calcium ions in the process of acetyltransferase activation during the formation of platelet-activating factor (PAF-acether). Biochem J. 1984;219(2):419-424. 


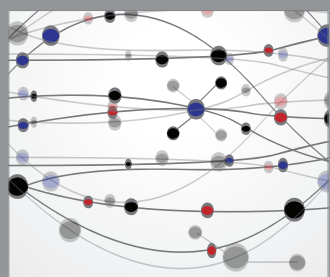

The Scientific World Journal
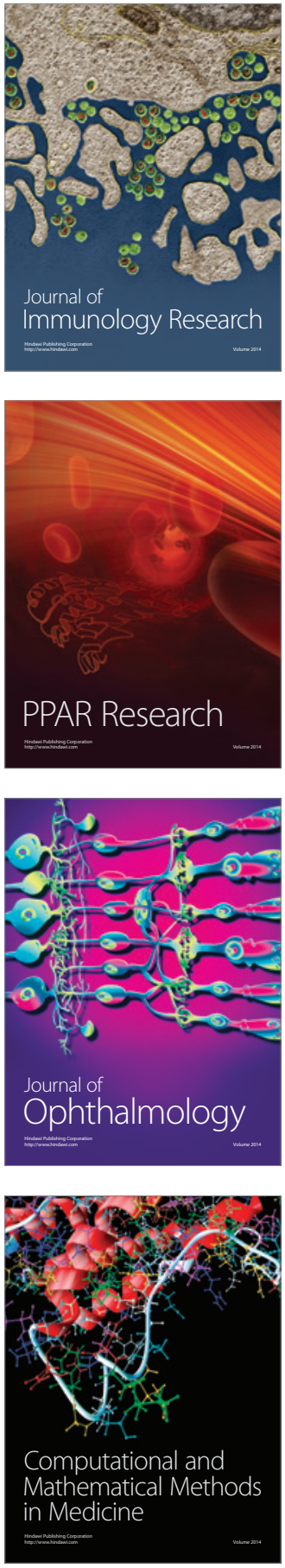

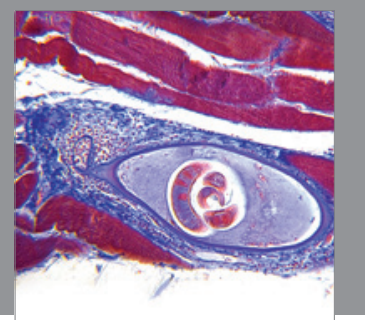

Gastroenterology

Research and Practice
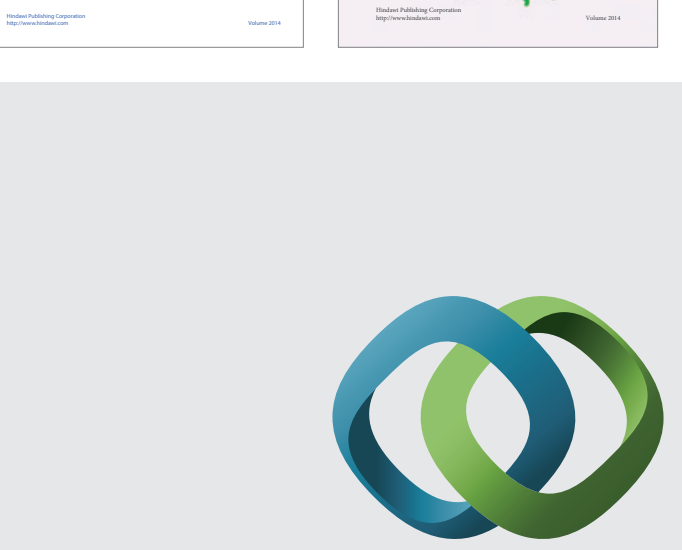

\section{Hindawi}

Submit your manuscripts at

http://www.hindawi.com
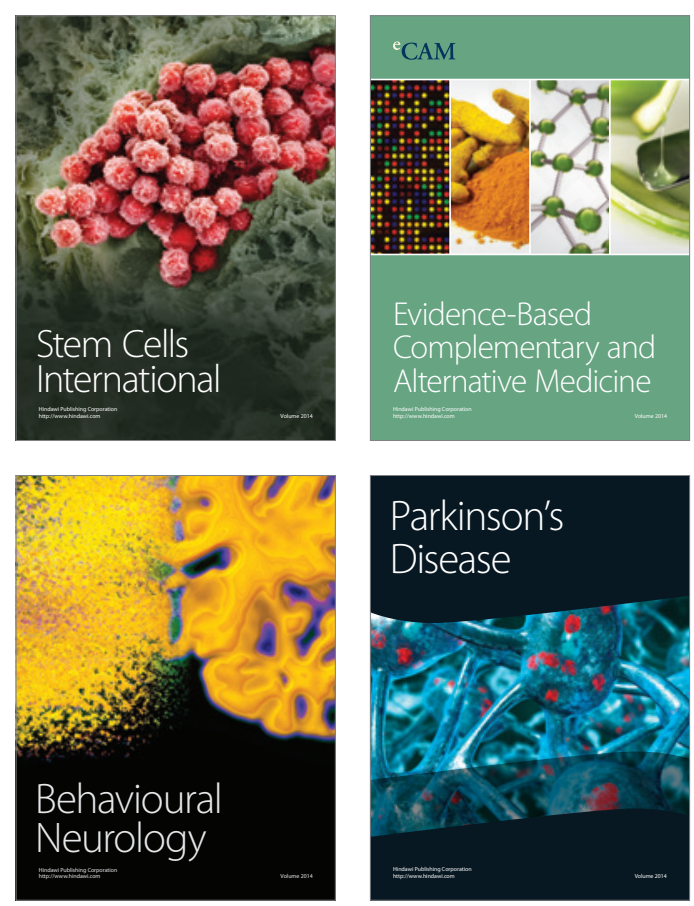

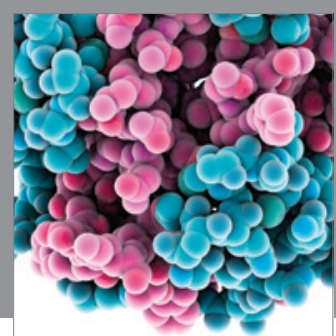

Journal of
Diabetes Research

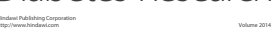

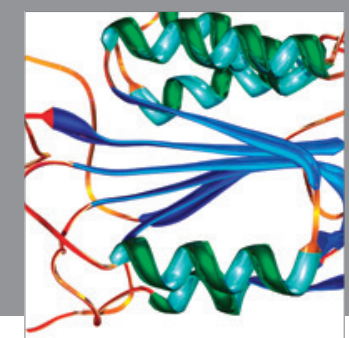

Disease Markers
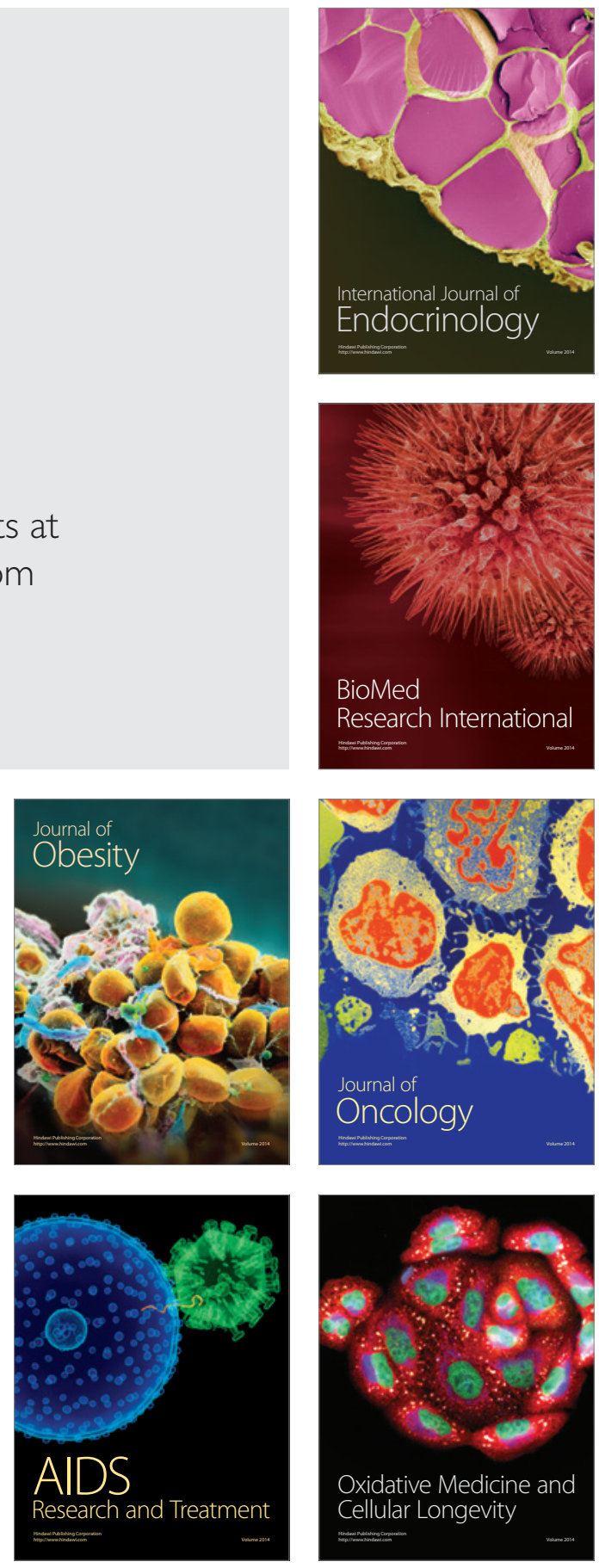